\title{
Gross Margin Analysis of Modern Groundnut Oil Extraction in Gombe Metropolis Gombe State, Nigeria
}

\author{
Saleh Abdullahi ${ }^{1, *}$, Kolo Abdulwahab ${ }^{2}$, Garba Sadiq Abubakar ${ }^{3}$ \\ ${ }^{1}$ Agricultural Economics and Extension Department, Federal University Kashere Gombe State \\ ${ }^{2}$ Agricultural Economics and Extension Department, Abubakar Tafawa Balewa University Bauchi \\ ${ }^{3}$ Department of Vocational and Technology Education, Abubakar Tafawa Balewa University Bauchi \\ *Corresponding author: abdussalihi@gmail.com
}

\begin{abstract}
The study examined the profit and market efficiency of small-scale modern groundnut oil extraction of RMP-12 and Ex-dakar varieties in Gombe Metropolis Nigeria. A multi-stage sampling technique was used to select 90 small-scale groundnut oil processors. Data were collected using structured questionnaires and were analysed using farm budget, sherphered-futrel and paired t-test models. The results revealed that costs of shelled groundnut constituted the major (92.3\% and 91.6\%) components of processing costs for RMP-12 and Ex-dakar groundnut varieties respectively. The gross ratio and operating ratio were all $<1$, meaning that the business was profitable. Also, the returns per naira of RMP-12 and Ex-dakar were 0.17 (\$0.0006) and 0.25 (\$0.0009) respectively. The marketing coefficient revealed Jekadafari markets (69.97\%) to be most efficients in the case of Ex-dakar products. The results further revealed $82.29 \%$ and $74.83 \%$ of the gross margins of respective RMP- 12 and Ex-dakar varieties were spent on marketing costs, with the remaining $17.71 \%$ and $25.17 \%$ were retained as the net profit and diffrence was significant $(\mathrm{P}<0.01)$. Despite the fact that RMP-12 variety gave higher gross income, the study concluded that the Ex-dakar variety performed better. Major impediments to profit and market efficiency were inadequate capital, high costs of shelled groundnut and transportation costs. It is therefore recommended that, the traders should have access to formal loans so as to improve productivity and efficiency.
\end{abstract}

Keywords: gross margin, efficiency, groundnut, extraction, small-scale

Cite This Article: Saleh Abdullahi, Kolo Abdulwahab, and Garba Sadiq Abubakar, "Gross Margin Analysis of Modern Groundnut Oil Extraction in Gombe Metropolis Gombe State, Nigeria." World Journal of Agricultural Research, vol. 5, no. 2 (2017): 58-63. doi: 10.12691/wjar-5-2-1.

\section{Introduction}

Edible oil extraction can be grouped into two: mechanical pressing and solvent extraction. Sometimes the latter compliments the former. For oilseeds with high oil content such as groundnut, first mechanical pressing will be applied and over $85 \%$ of the oil will be extracted. The remaining oil in the expeller cake will then be extracted with solvent. For some other oilseed with low oil content, solvent extraction is generally considered as the best alternative. However, the initial investment cost of solvent extraction is much higher than mechanical pressing. In addition, solvent extraction is more appropriate for large scale than small-scale enterprise [CSA] (2012). Therefore, for the purpose of this study the mechanical pressing technology has been focused.

Under normal circumstances groundnuts being the major raw materials of oil extraction and cake production flow from the farms and or rural markets to the processing plants in the urban centres where the demand is relatively high. The reason is that, most of the urban dwellers are civil servants and workers of service sectors other than farming, who do not have time and place to engage in production, processing and or marketing, hence depend largely on farm products [18]. The produce are assembled in big lots and move to bigger isolated urban markets. Standard units of measurement and pricing were established in groundnut oil and groundnut cake marketing; the oils are poured into gallons, jerry cans, bottles etc of different shapes and sizes, the cakes are bagged and weighted in tonnes. Despite groundnuts are seasoned crops, the oil millers partake in the business all year round [17]. There are many varieties of groundnut grown in Nigeria [8]. Some were considered 'traditional' but others have been introduced in the last few dacades; for instance the Yardakar (Ex-Dakar) and Maiborgo (RMP-12) which are known for their high content of edible oil [23].

According to Gombe State Economic Empowerment and Development Strategy [GOSEEDS] (2010), groundnut processing vis-à-vis oil extraction is a common socioeconomic activity found in the State; as increase in production leads to a derived demand of the outputs, necessitated the establishment of small, medium and large-scale processing plants so as to add value to the crop. But, the oil processing enterprise in the State is mainly dominated by small-scale operators, based in urban areas. Small-scale groundnut mills are commercially viable, returning an annual average of $51 \%$ on typical investments of between 0.5 million $(\$ 1,764)$ - 2.5 million 
(\$ 8,820), with profits of $21 \%$ on sales. The socioeconomic benefits of groundnut oil mills include: (i) A typical small-scale groundnut oil mill employs at least 10 wokers on a permanent basis and $3-5$ on temporary basis with an average monthly income that is 2.5 - 3 times the rural average incomes. (ii) The mills offer a ready cash market for groundnut. A typical mill buys several thousands of Naira worth of groundnut per year from many different markets across the country. (iii) Other beneficiaries are that, school children who collect bottles for recycling, fuel wood suppliers, roasting and separation of seeds and (local) maintenance workshops that repair the machines. This amount to a further twenty five beneficiaries, earning hundreds of Naira per year from a mill. (iv) Benefits accrue to the community through cheaper oil of good quality; typically the groundnut oil is relatively cheaper than the refined blended oils produced by the larger companies.

The profit and market efficiency of groundnut oil processing depends on reducing the capital and operating costs as much as possible, and at the same time maximising the income from the sales of oil and other byproducts. A careful study of all costs is therefore necessary before setting up a processing plant. In particular the cost of the main pieces of equipment, salaries for the expected number of workers, and the prices for raw materials, fuel and power should be assessed. The price that can be charged for oil and other by-products depends on a number of factors including quality, packaging, and the number, type and quality of competing products etc. These should each be assessed in order to predict the likely income at the planned scale of production over the year. The production costs can then be compared with the expected income to calculate the likely profitability. In most cases it is necessary to make full use of the by-products to make the enterprise financially successful [12]. It is worth while to study groundnut value chain to identify its processing and marketing efficiencies, to provide information that looks into the possible ways and means of increasing the traders' income through accumulating capital and enhancing productivity and marketing [17]. To this effect, the research is therefore made to provide answers to the following questions: (i) is groundnut oil processing profitable? (ii) is marketing efficiency of groundnut oil processing achieved? (iii) is there varietal difference in gross margin between RMP-12 and Ex-dakar? Thus; the specific objectives of the study were to: (i) ascertain the profitability of groundnut oil processing in the study area; (ii) determine the marketing efficiency of groundnut oil and groundnut cake in the study area; (iii) assess the gross margin differential between RMP-12 and Ex-dakar products.

\section{Methodology}

\subsection{The Study Area}

Gombe metropolis is the principal urban centre of Gombe State which serves as the State capital as well as the headquarters of Gombe Local Government Council. Situated on longitude $11^{\circ} 10^{\prime} \mathrm{E}$ and latitude $10^{\circ} 17^{\prime} \mathrm{N}$, with an altitude of 435.13 meters above sea level, covering an area of $5,200 \mathrm{~km}^{2}$ and had human population of 268,536, with males constituting $68.3 \%$ with a projection of 280,000 people in 2012 [10]. Gombe is a multi-ethnic town constituting mainly of Fulani, Hausa, Tera, Bolewa, Tangale, Kanuri etc; with the majority of the population engaged in agriculture and agro-allied investments. The weather is characterised by a warm climate, having a mean diurnal temperatures of $35^{\circ} \mathrm{C}-$ $40^{\circ} \mathrm{C}$ in the months of March - May and to a $<30^{\circ} \mathrm{C}$ during harmattan, and had mean annual rainfall of 850 $\mathrm{mm}$ [Gombe State Economic Empowerment and Development Strategy; GOSEEDS] [9].

\subsection{Sampling Procedure}

A multi-stage sampling technique was used to select 90 small-scale groundnut oil processors. In stage I, Gombe metropolis was purposively selected. The choice was made by the fact that it is the major commercial centre of the state and constituted about $85 \%$ of the target population for this study. In stage II, six market districts; Tudunwada, Jekadafari, Pantami, Herwagana, Bolari and Nassarawo were purposively selected because they were notable and predominant areas for small-scale groundnut oil processing and marketing. In stage III, two markets were selected each from the market districts. In stage IV, a total of 90 groundnut oil processors were selected using simple random sampling, proportionate to the number of marketers in each market.

\subsection{Sample Size}

In determining the sample size appropriate for this study, the Barlett et al. [4] model as modified by Alamu and Olukosi [3] was used, where $20 \%$ of the entire population was selected. According to this model, the appropriate sample size for a population of 451 traders was ninety (90). A proportional allocation technique was then used to determine the number of sample from each market.

\subsection{Data Collection}

Data for this study were collected using structured questionnaires; this was supported with personal interview in situations where the respondents did not understand the questions.

\subsection{Data Analysis}

Data were analysed using farm budget, profitability index, shephered-futrel and paired t-test models. To determine the costs, returns and net profit, the gross margin analysis as a popular model was used. According to Salako et al. [21], the Gross Margin (GM) equation is specified as;

$$
\mathrm{GM}=\mathrm{TR}-\mathrm{TVC} .
$$

But, Profit $=$ Total Revenue - Total Cost; expressed as;

$$
\pi=\mathrm{TR}-\mathrm{TC}
$$

also,

$$
\mathrm{TC}=\mathrm{TFC}+\mathrm{TVC}
$$


where:

$\mathrm{GM}=$ Gross Margin (

$\mathrm{TVC}=$ Total variable costs $(\mathrm{A})$

$\mathrm{TFC}=$ Total Fixed Cost $(\mathrm{N})$

$\mathrm{TR}=$ Total Revenue (

$\pi=$ Profit ( $)$.

The Shephered-futrel model was used to determine marketing efficiency of groundnut oil processing in the study area. Efficiency in agro-processing firms is the most frequently used measurement of market performance. Improved market performance is the common goal of agribusiness firms. The model is simplified as;

$\mathrm{M} . \mathrm{E}=\frac{\text { Costs of marketing of products }}{\text { Total value of marketing of the products }} \times 100 \%(4)$ where;

M.E = Marketing efficiency (coefficient).

The coefficient shows what percentage of the total revenue is taken up by the total costs. Therefore the lower the coefficient the better the marketing margin, hence the more efficient market is [22].

The Paired t-test analysis was used to assess the varietal difference in gross margin between RMP-12 and Ex-dakar products. The model is assumed appropriate to compare the means of two sample groups [26]. Generally the model is specified as;

$$
t=\frac{x_{1}-x_{2}}{\sqrt{\frac{x_{1}^{2}}{n_{1}}+\frac{x_{2}{ }^{2}}{n_{2}}}}
$$

where;

$\mathrm{t}=\mathrm{t}$-value

$\bar{X}_{1}$ and $\bar{X}_{2}=$ arithmetic means

$\mathrm{S}_{1}$ and $\mathrm{S}_{2}=$ variances of the two groups

$\mathrm{n}_{1}$ and $\mathrm{n}_{2}=$ sample sizes of the two group.

\section{Results and Discussion}

\subsection{Costs and Returns of Small-scale Groundnut Oil Processing Per Cycle Per Trader in Gombe Metropolis}

Cost comprises of the actual expenses incurred in the performance of the marketing activities as the commodity moves from the farm to the ultimate consumer. Costs in processing and marketing of groundnut products were grouped basically into two; the fixed costs and the variable costs, while returns were obtained from the sales of groundnut oil (GNO) and groundnut cake (GNC). The average total costs and returns from processing of average 3.12 tonnes of shelled groundnut per processing cycle of at least two days per week were determined and presented in Table 1. The results revealed that, the average total processing costs for RMP-12 was 417,959.13 (\$1,474.28) while that for Ex-dakar was 386,596.21 (\$1,363.66). Also, the results depicted that, fixed cost components were merely $0.31 \%$ and $0.34 \%$ of the average total costs of processing respective groundnut varieties. The costs of raw RMP-12 and Ex-dakar variety accounted for $92.25 \%$ and $91.25 \%$ of the average total costs respectively. In terms of returns, 23,649.61 (\$83.42) and 31,078.43 (\$ 109.62) were realised as gross margins from processing one tonne of RMP-12 and Ex-dakar respectively. Groundnut oil generated the major (67.54\% and 64.67\%) of the average gross incomes of RMP-12 and Ex-dakar respectively. This implies that, for traders to make sufficient profit they have to sell both the oil and the cake jointly. Similar findings were made by Daneji et al. [6] and Iliyasu et al. [13] both reported that, to cover up the variable costs and make sufficient profit, the groundnut oil and groundnut cake must be sold jointly.

Table 1. Costs and returns of small-scale groundnut oil extraction in Gombe metropolis per week per trader

\begin{tabular}{|c|c|c|c|c|c|c|}
\hline \multicolumn{3}{|c|}{ Elements } & \multicolumn{2}{|c|}{ Amount ( $¥)$} & \multicolumn{2}{|c|}{ Relative \% of TC } \\
\hline Variable Costs & Quantity & Unit & RMP-12 & Ex-dakar & RMP-12 & Ex-dakar \\
\hline Cost of shelled groundnut & 3.12 & tonnes & $385,576.52$ & $354,213.60$ & 92.25 & 91.62 \\
\hline Salt & 25.2 & grams & 98.83 & 98.83 & 0.023 & 0.026 \\
\hline Onion & 0.95 & $\mathrm{~kg}$ & 184.67 & 184.67 & 0.044 & 0.048 \\
\hline Water & 300 & litres & 154.22 & 154.22 & 0.037 & 0.04 \\
\hline Firewood fuel & 250 & $\mathrm{~kg}$ & 269.69 & 269.69 & 0.064 & 0.07 \\
\hline Advertisement & . & . & 134.66 & 134.66 & 0.032 & 0.035 \\
\hline Transportation & . & . & $5,368.56$ & $5,368.56$ & 1.28 & 1.39 \\
\hline Labour & 4 & Man day & $7,805.56$ & $7,805.56$ & 1.858 & 2.017 \\
\hline Security & 1 & night & 330.3 & 330.3 & 0.079 & 0.085 \\
\hline Plastic oil containers & 65 & . & $15,676.66$ & $15,676.66$ & 3.731 & 4.051 \\
\hline Poly-sacks & 22 & . & $1,031.34$ & $1,031.34$ & 0.245 & 0.266 \\
\hline Total Variable Costs & & & $416,631.01$ & $385,268.09$ & 99.69 & 99.66 \\
\hline \multicolumn{7}{|l|}{ Fixed Costs } \\
\hline Other fixed costs & & & 806.95 & 806.95 & 0.19 & 0.21 \\
\hline Total Fixed Costs & & & $1,328.12$ & $1,328.12$ & 0.31 & 0.34 \\
\hline Total Costs & & & $417,959.13$ & $386,596.21$ & 100 & 100 \\
\hline Returns & & & & & \multicolumn{2}{|c|}{ Relative \% of TR } \\
\hline Oil & & & $331,215.56$ & $311,875.00$ & 67.54 & 64.67 \\
\hline Cake & & & $159,202.22$ & $170,357.78$ & 32.46 & 35.33 \\
\hline Total Returns & & & $490,417.78$ & $482,232.78$ & 100 & 100 \\
\hline Gross Margin & & & $73,786.77$ & $96,964.69$ & & \\
\hline Net Profit & & & $72,458.65$ & $95,636.57$ & & \\
\hline
\end{tabular}


The result also agrees with Olumakinde [20], who reported that 20,000.00 (\$70.55) - 30,000.00 (\$ 105.82) profits were made from processing one tonne raw groundnut in South-eastern Nigeria. This translates that the business was profitable, as further confirmed by the rate of return to investment (ROR) (17.34\% and $24.74 \%)$ meaning that for every 1 (\$ 0.004) invested, 0.17 (\$ 0.0006) and 0.25 (\$ 0.0009) were realised as net returns from RMP-12 and Ex-dakar respectively. This also in line with Danwanka et al. [7] and Haruna et al. [11] both reported that, groundnut oil processing and marketing was profitable business in Bauchi State. Although, groundnut oil processing from the foregoing analysis is profitable but the level of profit is low. The reason for low profitability could be as a result of low price paid for the products, coupled with high cost of groundnut seeds [13].

\subsection{Profitability of Small-scale Groundnut Oil Extraction in Gombe Metropolis}

Profitability analysis is a component of enterprise resource planning that allows traders to forecast the profitability of a proposal or to optimise the profitability of an existing business. It can anticipate sales and profit potential, specific to aspects of the market, such as customers' socioeconomic status or product types [16]. The profitability or financial ratios used to measure solvency position and financial success of groundnut oil extraction in this study include: gross ratio (GR), operating ratio (OR), rate of return to investment (ROR), ratio of gross margin to variable costs, and ratio of gross margin to fixed costs as presented in Table 2. Gross ratio shows the relationship of total revenue to the total costs. The GR evaluates the performance of the business, such that lower ratio of $<1$ is considered desirable [6]. This entails higher returns per Naira invested. From the results, the gross ratio for RMP-12 variety (0.8523) and Ex-dakar variety $(0.8017)$ were recorded. This implies $85.23 \%$ and $80.23 \%$ of the total revenues give to pay for the total costs of processing RMP-12 and Ex-dakar respectively. This suggests a reason that Ex-dakar gave higher average net return than the RMP-12 variety.

Operating ratio is a ratio of a firm's variable costs to its total revenue. A positive and lower ratio of $<1$ is desirable as this indicates that in the event of decline in sales or revenue, the firm will maintain its profitability status. A lower ratio is an indicator of operational efficiency of a business especially when compared to same ratio for competitors. The OR does not guaranty debt repayment or expansion of the firm's venture. Table 2 shows operating ratio of 0.8495 and 0.7989 for RMP-12 and Ex-dakar, respectively. Meaning that $84.95 \%$ and $79.89 \%$ of the total revenue were used to pay for the variable (operating) costs of the respective groundnut varieties, that (Ex-dakar) with a lower ratio tends to have higher profit.

The rate of return to investment was 0.1734 for RMP-12 and that for Ex-dakar was 0.2474, which further confirmed the relative profitability of the two groundnut varieties; meaning that for every one naira invested; \# 0.17 (\$ 0.0006) and 0.25 (\$0.0009) were realised respectively. This is similar with the findings of Adinya
[1], who reported 0.22 (\$ 0.0008) returns per naira invested in groundnut products marketing in Bekwarra Local Government Area, Cross River State. Also, Iliyasu et al. [13] recorded the net return on groundnut processing in Maiduguri metropolis as $40 \%$ of the total investment, which means for every one naira invested, 40 kobo was realised. Since the prevailing interest rate on savings is $20 \%$, therefore, it is better to invest in groundnut oil processing than to save money in a bank.

Table 2. Profitability analysis of processing RMP-12 and Ex-dakar groundnut varieties

\begin{tabular}{lcc}
\hline Profitability indicators & Ratio (RMP-12) & Ratio (Ex-dakar) \\
\hline Gross Ratio & 0.8523 & 0.8017 \\
Operating Ratio & 0.8495 & 0.7989 \\
Returns per Naira invested & 0.1734 & 0.2474 \\
\hline
\end{tabular}

\subsection{Marketing Efficiency of Groundnut Products}

Marketing efficiency is viewed as the maximisation of the ratio of output to input in marketing, expressed as percentage [14]. To determine the marketing efficiency of groundnut oil and cake, the Shephered - Futrel model was employed. This model was considered accurate for measuring marketing efficiency of most agro-processed products [25]. Table 3 shows that RMP-12 variety's oil and cake in Herwagana markets had the least marketing margin of $8.59 \%$, this implies that $100 \%$ retail price paid by the final consumer, result in farm-to-retail price spread of only $8.56 \%$. In other words, an average RMP-12 processor in Herwagana markets earns marketing margin of 0.086 ( $\$ 0.0003$ ) for every $1(\$ 0.004)$ retail price paid by the final consumer in the marketing process. This represents payments for all assembling, processing, transporting, and retailing charges added to farm products. The low level of marketing margin of the processors is attributed to exploitative activities of the middlemen. The finding contradicts Jongur \& Ahmed (2008), that farmer's margin was as high as $96.81 \%$; that only $3.19 \%$ went to middlemen involved in grains marketing in Adamawa central zone.

Moreover, the Herwagana markets were regarded less efficient base on market coefficient $(96.80 \%)$, implying that only $3.20 \%$ of the total revenues that were received by the processors. This may be due to monopolistic behaviour in the markets, imperfect competition, price variation of the raw materials and transportation costs. However, the results further revealed that, Ex-dakar variety's oil and cake in Jekadafari markets had the most marketing margin of $35.50 \%$, this implies that, $100 \%$ retail price paid by the final consumer result in farm-to-retail price spread of only $35.50 \%$. In other words, an average Ex-dakar processor in these markets earns a market margin of 0.36 (\$ 0.0013) for every 1(\$0.004) retail price paid by the final consumer in the marketing process. Jekadafari markets having $69.97 \%$ market coefficient for Ex-dakar's oil and cake, were most efficient. Meaning that out of the total revenues, $30.03 \%$ went to the processors while the remaining proportion went to other middlemen. 
The results also showed the marketing efficiencies of Nassarawo as $(82.25 \%$ and $77.73 \%$ ), Bolari as $(82.71 \%$ and $78.20 \%$ ), Pantami as $(79.03 \%$ and $72.25 \%)$ and Tudunwada as $(89.44 \%$ and $84.17 \%)$ for respective RMP-12 and Ex-dakar varieties. In comparison, Exdakar's products revealed to have lower coefficients than that of RMP-12 in all the markets; thus, concluded that those markets were most efficient. This was attributed to the fact that the Ex-dakar variety had lower processing costs and higher marketing margin than the RMP-12 variety. To improve the market efficiency and marketing margin, the processors should either increase the firm's gate price or to possibly by-pass the market middlemen to get higher return from the sales [19]. This agrees with Nzima et al. [17], who in their findings reported Santhe market was the most efficient $(53.70 \%)$ as compared to other markets in Mzimba \& Kasungu districts of Northern and Central Malawi respectively.

This was attributed to the fact that most of groundnut processors sold their products direct to the consumers. Also Tijjani et al. [24] revealed the marketing efficiency of $32.67 \%$ was obtained in dried processed products in Maiduguri metropolis Borno State, Nigeria. This reveals that dried processed products marketers received about $67.33 \%$ per $50 \mathrm{~kg}$ cartoon as net profit. Aidoo et al. (2013) reported similar findings that groundnut marketing was found to perform better when compared to other oil producing crops in Northern Ghana. While the groundnuts' products traders realised $93.36 \%$ as marketing margin, the Soybeans' products traders obtained $57.22 \%$ marketing margin. But, Bipradas [5] argued that efficiency of agricultural markets cannot be judged solely by the structure-conduct-performance framework or by the marketing margin analysis only, it needs to be backed up with some additional evidences of competitive conditions like low inter-market price differentials, possibility of inter-market trade, etc.

\subsection{Varietal Comparative Gross Margin of RMP-12 and Ex-dakar Products in Gombe Metropolis}

A gross margin for an enterprise is its financial output minus its variable costs. Gross margins however, should only be compared with figures from firms with similar characteristics and production systems. With this reservation in mind, the comparisons can give useful indication of the production and economic efficiency of an enterprise. Gross margin indicates how much has been paid for the processing and marketing services applied to the products at a particular stage in the marketing process. It is thus the first step in providing the factual information necessary to dispel the misconceptions which frequently arise when assessing the performance of the food marketing system [15]. In agricultural marketing, gross margins are useful for planning and for making comparisons of enterprises in the same firm (Lampkin, 2001). Table 4 reveals that the gross margin of Ex-dakar products was generally higher $(\mathrm{P}<0.01)$. This was because despite the fact that RMP-12 variety gave higher gross incomes, but Ex-dakar variety incurred less processing and marketing costs. The relatively lower marketing margin, lower net profits and higher processing costs of RMP-12 variety, corroborates the findings of Achike and Anzaku [2], who reported that competitive pressure sets in, and reduced net incomes when the outputs (oil and cake) were sold. Gross margin has remained an important tool in analysing the performance of marketing systems. The marketing costs and the gross margins can both be indicators of efficiency or inefficiency of marketing systems. The results further revealed $82.29 \%$ and $74.83 \%$ of the gross margins of RMP-12 and Ex-dakar were spent on marketing costs with the remaining $17.71 \%$ and $25.17 \%$ were retained as the net profit. As a guide to select the best variety, their gross margins were compared, and Ex-dakar was arbitrarily found to perform better.

Table 3. Marketing efficiency of groundnut oil and cake in Gombe metropolis

\begin{tabular}{|c|c|c|c|c|c|c|c|}
\hline Markets & Varieties & SC ( $)$ & MC (N) & TC ( & SP (\#) & VA (N) & ME(\%) \\
\hline \multirow[t]{2}{*}{ Tudunwada } & RMP-12 & $379,439.99$ & $22,003.38$ & $401,443.37$ & $448,838.46$ & $69,398.47$ & 89.44 \\
\hline & Ex-dakar & $348,720.00$ & $22,003.38$ & $370,723.38$ & $440,453.85$ & $92,733.85$ & 84.17 \\
\hline \multirow[t]{2}{*}{ Jekadafari } & RMP-12 & $384,072.00$ & $27,395.41$ & $411,467.41$ & $549,300.00$ & $165,228.00$ & 79.91 \\
\hline & Ex-dakar & $350,064.00$ & $27,395.41$ & $377,459.41$ & $539,450.00$ & $189,386.00$ & 69.97 \\
\hline \multirow[t]{2}{*}{ Pantami } & RMP-12 & $389,479.99$ & $25,360.30$ & $414,840.29$ & $524,904.17$ & $135,424.18$ & 79.03 \\
\hline & Ex-dakar & $343,408.01$ & $25,360.30$ & $368,768.31$ & $510,400.00$ & $166,991.99$ & 72.25 \\
\hline Herwagana & Ex-dakar & $381,490.92$ & $24,152.08$ & $405,643.00$ & $444,563.64$ & $63,072.72$ & 91.25 \\
\hline \multirow[t]{2}{*}{ Bolari } & RMP-12 & $381,296.85$ & $23,343.98$ & $404,640.83$ & $489,210.53$ & $107,913.68$ & 82.71 \\
\hline & Ex-dakar & $356,829.47$ & $23,343.98$ & $380,173.45$ & $486,176.32$ & $129,346.85$ & 78.20 \\
\hline \multirow[t]{2}{*}{ Nassarawo } & RMP-12 & $380,065.92$ & $24,072.03$ & $404,137.95$ & $491,346.00$ & $111,280.08$ & 82.25 \\
\hline & Ex-dakar & $349,926.72$ & $24,072.03$ & $373,998.75$ & $481,128.00$ & $131,201.80$ & 77.73 \\
\hline \multicolumn{2}{|c|}{ Mean } & $371,221.54$ & $24,387.86$ & $395,609.40$ & $487,846.07$ & $116,707.91$ & 81.09 \\
\hline
\end{tabular}

NB: $\mathrm{SC}=$ Supply costs; $\mathrm{MC}=$ Marketing costs; $\mathrm{TC}=$ Total costs; $\mathrm{SP}=$ Selling price; VA = Value added; $1=\$ 283.50$.

Table 4. Gross margin differential between RMP-12 and Ex-dakar products

\begin{tabular}{|c|c|c|c|c|c|c|}
\hline \multirow[b]{2}{*}{ Variables } & \multirow[b]{2}{*}{ Average Gross Margin } & \multicolumn{5}{|c|}{ Paired sample test } \\
\hline & & Mean & S.E & df & t-values & P-value \\
\hline RMP-12 & 73,786.77 (\$260.27) & 7,013 & $2,647.022$ & 89 & $2.650 * * *$ & 0.01 \\
\hline Ex-dakar & 96,964.69 (\$347.03) & & & & & \\
\hline Difference in GM & 23,177.92(\$ 81.75) & & & & & \\
\hline
\end{tabular}

*** Significant $\mathrm{P}<0.01 ; \mathrm{GM}=$ Gross Margin; $1=\$ 283.50$. 


\section{Conclusion}

Based on the results obtained from this study, it may be concluded that the enterprise is profitable, the Ex-dakar variety gave higher gross income which was significant. The traders were small-scale with inadequate capital, this was because they do not have enough credit facilities. The shelled groundnut was the most important resource input for oil and cake production, that increase in groundnut seed would give additional income. The results revealed that costs of shelled groundnut constituted the major components of processing costs of the respective groundnut varieties. The financial ratios employed and as well as the returns per naira invested revealed that the business was profitable in the study area.The coefficient of marketing revealed Jekadafari markets were mosts efficient in the case of Ex-dakar varieties.

\section{Recommendations}

In order to achieve sufficient profit and efficient market of groundnut products, the following recommendations were made:

1. The traders should be encouraged to join cooperative associations to have access to formal loans for expansion, and to create other market linkages with a view of maximising advantages of distant markets.

2. The needed infrastructures such as; electricity, good roads, storage facilities etc should be adequately provided by the government in order to reduce marketing costs.

3. Government and other lending agencies should do more to assist the traders with soft loans; this will help solve the problem of inadequate capital.

4. The processors should be encouraged to embark on Ex-dakar variety as their main resource input based on its high gross margin. Marketing operations should be improved for enhanced efficiency in all the markets in the study area

\section{References}

[1] Adinya, I. B. "Analysis Of Costs-Returns Profitability in Groundnut Marketing in Bekwarra Local Government Area Cross River State, Nigeria". The Journal of Animal \& Plant Sciences, 19(4): 212-216. 2009.

[2] Achike, A. I and Anzaku, T. A. K. "Economic Analysis of the Marketing Margin of Benniseed in Nasarawa State, Nigeria". Agro-Science Journal of Tropical Agriculture, Food, Environment and Extension, 9(1): 47-55. 2010

[3] Alamu, J. F. and Olukosi, J. O. Simplified Research Methodology: Principles and Practices (revised edition), Great Glory Publishers, Zaria, 2010, 13-20.

[4] Bartlett, J. E., Kotrilik, J. W and Higgins, C. C. "Determining Appropriate Sample Size in Survey Research". Information Technology, Learning and Performance Journal, 19(1): 5-12. 2001.

[5] Bipradas, R. "Studies on Marketing Efficiency of Agricultural Products in India": A Critical Evaluation, International Journal of Multidisciplinary Research and Development, 1(7): 205-210. 2014.

[6] Daneji, M. I., A. I. Malumfashi and Muhammed, S. G. "Profitability Analysis of Groundnut Production in Bauchi LGA of Bauchi State Nigeria". Savannah Journal of Agriculture, 1(2): 165-170. 2006.

[7] Danwanka, H. A., A. Y. Iliyasu and Isa, M. "Economics of Local extraction of oil from groundnut in Bauchi Metropolis". Journal of League of Researchers in Nigeria 6(1): 57-60. 2005.

[8] Gibbon, D. and A. Pain, (1988). Crops of the of Northern Nigeria: Drier Regions of the Tropics, University of Wisconsin, Longman Group, pp 121-157.

[9] GOSEEDS, (2007). Gombe State Economic Empowerment and Development Strategy: Handbook, Abuja, Dandafid Nig. Ltd, pp 11.

[10] G.S.G. (2013). Gombe State Government: General Information, retrieved from; http://www.en.wikipedia.org/wiki/Gombe.State: On 30/01/2014.

[11] Haruna, U., Murtala, N and Ahmed, H. S. (2006). Economics of Groundnut Processing Among the rural women of Katagum Local Government Area of Bauchi State Nigeria. Savanna Journal of Agriculture, 1(2): 138-144.

[12] Haruna, U., Sani, M. H., Danwanka, H. A. and Adejo, E. (2012). Economic Analysis of Fresh Tomato Marketers in Bauchi Metropolis of Bauchi state, Nigeria. Nigerian Journal of Agriculture, Food and Environment. 8(3): 1-8.

[13] Iliyasu, A., Wulet, I., and Yusuf, K. (2008). Profitability Analysis of Groundnuts Processing in Maiduguri Metropolitan Council of Borno State, Nigeria. Nigerian Journal of Basic and Applied Sciences, 16(2): 253-256.

[14] Jabir, Y. I. (2009). Marketing of Selected Processed Dairy Products in Bauchi State Nigeria, M.Sc. Thesis submitted to the department of Agricultural Economics, A.T.B.U. Bauchi (unpublished), Pp 113

[15] Lawrence, D. S. (1992). Marketing and Rural Finance Service $(A G S M)$ : Agricultural Service Division Food and Agricultural Organisation, Rome, Glasgow University Press, pp 34.

[16] Margaret, R. (2015). Business Intelligence, NY, USA, TechTarget, Pp 467

http://searchfinancialapplications.techtarget.com/definition/profita bility-analysis/.

[17] Nzima, W. M., Dzanja, J. and B. Kamwana, (2014). Structure, Conduct and Performance of Groundnuts Markets in Northern and Central Malawi: Case Studies of Mzimba and Kasungu Districts. International Journal of Business and Social Science 5(6): 130-139.

[18] Ogunwale, A. B., Ayinde, A.T., AbdulAzeez, A. and Adebayo, R. O. (2002). Agricultural Economics and Statistics for Undergraduate Sudents, Kano, Flash Printers and Publishers Pp 232

[19] Okonkwo, K. N. (2013). Analysis of Poultry Feeds Marketing in Ahiazu-Mbaise Local Government Area in Imo State. Journal of Marketing and Consumer Research, 1(2): 76-82.

[20] Olumakinde, O. (2013), Groundnut Oil Processing Factory: A Business Day Media Publications Ltd. Published on; 03/02/2014. http://www.businessdayonline.com.

[21] Salako, A. A., Olubanjo, O. O. and Okeowo, T. A. (2013). Comparative Cost-Returns Structures of Irrigated and Rainfed Arable Crops Production in Ogun-Oshun River Basin Development Authority Project Areas. International Journal of Food and Agricultural Research, 10 (1\& 2): 34-42.

[22] Sherpherd, G. S. and Futrel, G. A. (1982). Marketing Farm Products: Economic Analysis, Amens, Iowa State University Press pp 36.

[23] Sokoto, M. B., I. Bello, and E. A. Osemuahu, (2013). Effects of Intra-Row Spacing on Yields of Two Groundnut (Arachis hypogaea L.) Varieties in Sokoto, Semi-Arid Zone, Nigeria. International Journal of Applied Agricultural and Apicultural Research, 9(1 \& 2): 11-17.

[24] Tijjani, B. A., Ismail, A., Goni, M. and Fannami, A. M. (2014). Analysis of Conduct and Performance of Dried Fish Market in Maiduguri Metropolis of Borno State, Nigeria. Journal of Economics and Sustainable Development, 5(5): 38-46.

[25] Ugwumba, C. O. A. (2009). Analysis of Fresh Maize Marketing in Anambra State, Nigeria. Journal of Research in National Development, 7(2): 1-9.

[26] Williams, M. K. T. (2006). Research Method Knowledge Base: The Statistical Analysis of the Post-test-only Randomized Experimental Design, New York, Lund Research Ltd. pp 42. 